\title{
Natural stochasticity vs. management effort: use of year-to-year variance for disentangling significance of two mutually confounding factors affecting water quality of a Norwegian cold dimictic lake
}

\section{A. T. Romarheim ${ }^{1,{ }^{\star *}}$, K. Tominaga ${ }^{2,3,{ }^{*}}$, G. Riise ${ }^{1}$, and T. Andersen ${ }^{2}$}

${ }^{1}$ Department of Environmental Sciences, Norwegian University of Life Sciences, Ås, Norway ${ }^{2}$ Department of Biosciences, University of Oslo, Oslo, Norway

${ }^{3}$ Norwegian Institute for Water Research, Oslo, Norway

"now at: Centre for Ecological and Evolutionary Synthesis (CEES), Department of Biosciences, University of Oslo, Oslo, Norway

"deceased

Received: 10 August 2014 - Accepted: 20 October 2014 - Published: 10 November 2014 Correspondence to: K. Tominaga (koji.tominaga @ibv.uio.no)

Published by Copernicus Publications on behalf of the European Geosciences Union.

Natural stochasticity

vs. management effort

A. T. Romarheim et al.

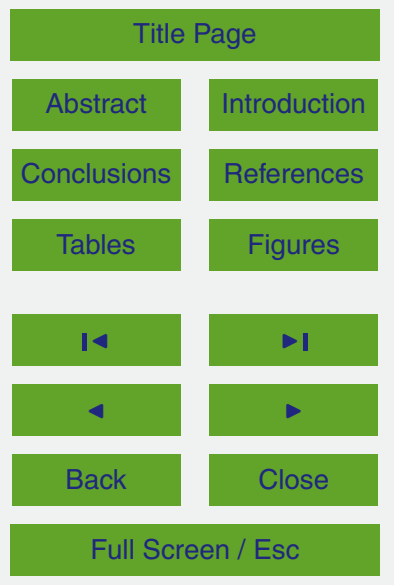

Printer-friendly Version

Interactive Discussion

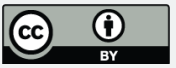




\section{Abstract}

Natural stochasticity can pose challenges in managing the quality of the environment, or hinder understanding of the system structure. It is problematic because unfavourable stochastic event cancels the costly management effort and because 5 favourable stochastic event overestimates success of the management effort. This paper presents a variance-based modelling method that can be used to quantify the extent to which the natural stochasticity can affect the target environment. We use a case study of a lake water quality assessment in a Norwegian lake of Årungen, together with a lake model MyLake, in order to present the method, and how this method could aswas to disentangle the respective significance of nutrient loading (management) and weather (the confounding natural stochasticity). Many scientifically and managerially relevant understandings have been revealed. For example, variation in runoff volume was most prevalent during autumn and winter, while variation in phosphorus inflow was most extensive from late winter to early spring. Thermal related properties in the lake were mostly determined by weather conditions, whereas loading was the most important factor for phytoplankton biomass and water transparency. Mild winters and greater inputs of suspended matter and phosphorus were followed by increased phytoplankton biomass and light attenuation. These findings suggest also that future changes in the global climate may have important implications for local water management decisionmaking. The present method of disentangling mutually confounding factors is not limited to lake water quality studies and therefore should provide certain utility in other application field of modelling.

\section{Introduction}

25 Natural stochasticity sometimes presents challenges in maintaining the quality of the environment. Such is the case for reducing nutrient loading in the hope for making
HESSD

$11,12489-12518,2014$

Natural stochasticity

vs. management effort

A. T. Romarheim et al.

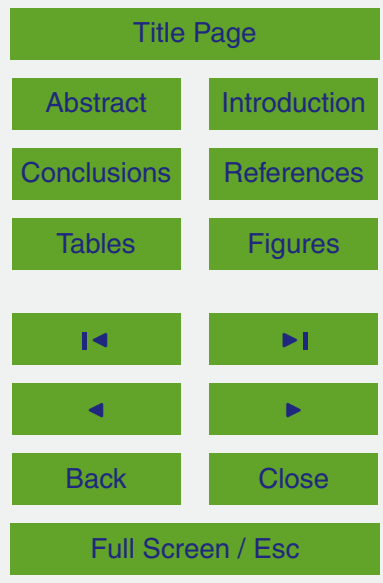

Printer-friendly Version

Interactive Discussion 
the quality of downstream lake better. Natural variation in weather for example may confound costly abatement efforts by counteracting the abatement of nutrient loading. Under this kind of challenge, it is paramount to evaluate to what extent the confounding variable can actually make significant difference in the management goal. The present 5 study illustrates how a variance-based modelling method could answer scientific and managerial questions, with a test case study of water quality of a Norwegian lake.

Scientific community has learnt that nutrient enrichment of lakes may lead to high phytoplankton mass development, low water transparency, and fish mortality due to oxygen depletion (Smith et al., 1999). Mainly two factors affect the nutrient loading to 10 lakes: (1) the soil and land use in the lake catchment, and (2) the hydrology of the watershed. Phosphorus is generally regarded as the determining nutrient for phytoplankton production in freshwater lakes (Schindler, 1977). Much effort has therefore been given to reduce phosphorus input to aquatic ecosystems, which has demonstrably led to reduced phytoplankton production and increased water transparency in many 15 lakes in Europe and North America (Jeppesen et al., 2005). On the other hand, many lakes have showed delayed or negligible improvements in water quality despite reduced nutrients loading (Jeppesen et al., 2007a).

Year-to-year weather variation has also been recognised to affect physical, chemical and biological processes in lakes (Bailey-Watts and Kirika, 1999; Blenckner et al., 2007; Jeppesen et al., 2009, 2007b; Whitehead et al., 2009). Increase in air temperature has been shown to increase the water temperature (George et al., 2007) and the stability of thermal stratification (Straile et al., 2003a), change the phytoplankton community towards dominance of species adapted to warmer water (Weyhenmeyer et al., 2002), and possibly lead to earlier and higher phytoplankton production (Huber et al., 2008; Weyhenmeyer et al., 2002). The changes in thermal conditions and mixing regime can in turn influence the light, oxygen and nutrient dynamics in the lake, and thereby impact the phytoplankton primary production and community structure (Tirok and Gaedke, 2007; Wilhelm and Adrian, 2008). Precipitation is also deemed as an
HESSD

$11,12489-12518,2014$

Natural stochasticity

vs. management effort

A. T. Romarheim et al.

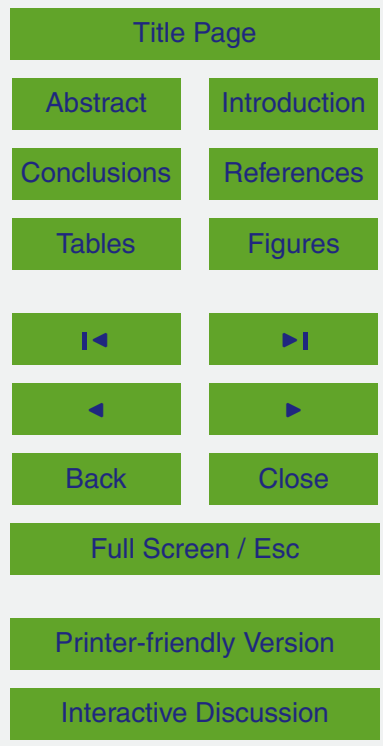


important factor determining the water transparency, runoff intensity, and suspended matter discharge (Arheimer et al., 2005; Nõges et al., 2007; Ulén et al., 2007).

Norway has, generally, a low fraction of arable land (3\%) and low population density $\left(12\right.$ persons $\mathrm{km}^{-2}$ ), so eutrophication is mainly recognizable in intensive agricul5 tural districts at low altitudes. Lake Årungen is situated in a developed agricultural area south-east in Norway, and is one of the most nutrient rich lakes in the country. Geological studies suggest that the natural phosphorus concentration of lakes in this area is $7-8 \mathrm{mg} \mathrm{m}^{-3}$ (Borch et al., 2007). Eutrophication became a problem in the lake during the 1960s, with phosphorus concentration exceeding $400 \mathrm{mg} \mathrm{m}^{-3}$ in the 1980 s (Løvs10 tad and Krogstad, 1993). Algal blooms, low water transparency, malodorous water, reduced fish stocks, and occasional mass mortality of fish were observed in the lake in this period (Ensby et al., 1984). Heavy algal blooms still occur, despite investments in sewage treatment and extensive changes in agricultural practices since the 1970 s to reduce nutrient leaching and erosion from the catchment.

15 Predicting eutrophication responses to nutrient loading is a complex task due to the stochastic dynamics of lake's response to weather, the confounding factor. Here we used one of the lake models based on system of processes that have been identified as a primary tool for improving our understanding of recovery and progression of eutrophication (Mooij et al., 2010). More precisely, we made combinations of forcing data (meteorological and nutrient loading inputs) for the model, with

1. some forcing data being the actual records and

2. others being the average day-to-day record for the period of 16 years, repeated 16 times.

This approach criss-cross the day-to-day and year-to-year variability in a systematic 25 way, and simulation outputs based on dissimilar combinations of these "actual" and "repeated avarage year" can be analysed once again from the day-to-day and yearto-year variability. In principle, the actual data are more variable than the repeated average year. If a particular forcing variable is significant in affecting the lake water 12492

\section{HESSD}

$11,12489-12518,2014$
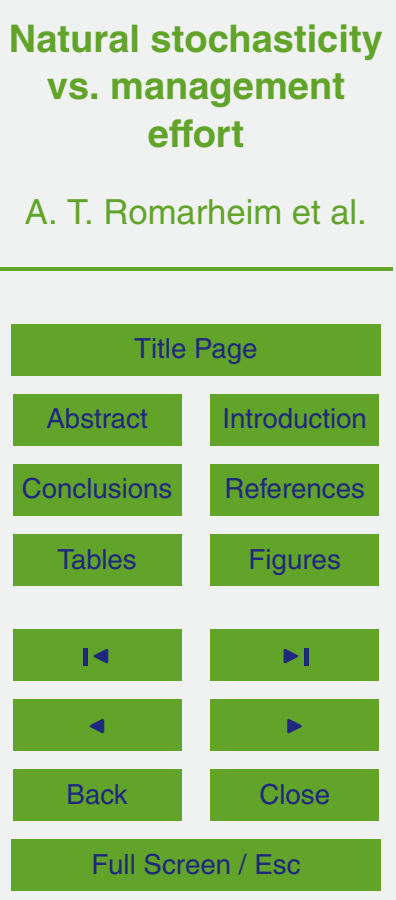

Printer-friendly Version

Interactive Discussion 
quality, switching from the actual data to repeated average year reduces the year-toyear variation in lake water quality variables. Combinations of these two types of forcing data are described in Sect. 2.5. This approach of comparing to average year by opting in the average year for a selected variable is used in a slightly different context by 5 Jöhnk et al. (2008), with a difference being that the "average year" was taken from one candidate year in Jöhnk et al., while the "average year" in the current study was indeed day-of-year-specific year-to-year average. More importantly, the current study demonstrates the use of year-to-year variance for each day of year, which is a powerful visual and quantitative tool in detecting the critical season for a variable.

10 The main aim of the current study is to evaluate the relative importance of year-toyear variation of two major factors, namely meteorological forcing and nutrient loading, contributing to lake's physical, chemical and biological conditions. We also visually inspect how their respective significance varies over the season. To this aim, (1) the MyLake model (Saloranta and Andersen, 2007) was first calibrated against the lake data,

(2) then various meteorological and nutrient loading scenarios combining variation of these two major factors were applied, and finally (3) the predicted lake responses were compared among different scenarios, in particular, the variance among years, rather than the absolute value of the predictions.

\section{Material and methods}

\subsection{Study site}

Lake Årungen is a dimictic lake with maximum and average depths of 13 and $8 \mathrm{~m}$, respectively. The lake is located in south-east Norway $\left(59^{\circ} 41^{\prime} 18^{\prime \prime} \mathrm{N}, 10^{\circ} 44^{\prime} 38^{\prime \prime} \mathrm{E}\right.$; Fig. 1), $25 \mathrm{~km}$ south of Oslo, and has a surface area of $1.2 \mathrm{~km}^{2}$. The catchment area covers $51 \mathrm{~km}^{2}$, where $53 \%$ is agricultural land, $34 \%$ forestry, $10 \%$ densely populated and $3 \%$ open water surfaces. The lake is highly exposed to agricultural runoff that causes high nutrient and particle loading. Runoff is mainly through 6 streams of 1.5 to $5 \mathrm{~km}$ length.

\section{HESSD}

$11,12489-12518,2014$

Natural stochasticity

vs. management effort

A. T. Romarheim et al.

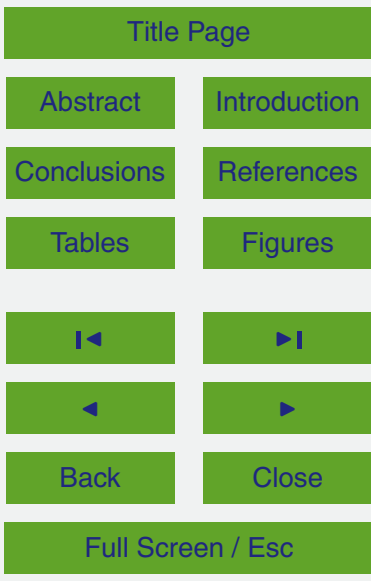

Printer-friendly Version

Interactive Discussion 
The outlet connects the lake to the marine environment as Lake Årungen enters the Oslofjord through a $3 \mathrm{~km}$ long stream.

\section{HESSD}

\subsection{Model}

MyLake is a one-dimensional lake model, adapted from MINLAKE (Riley and Stefan, 5 1988), which simulates daily changes in physical and chemical dynamics over the depth gradient (Saloranta and Andersen, 2007). The model simulates ice and snow dynamics in a mechanistic manner and it has been applied to winter-freezing lakes in Norway and Finland (Kankaala et al., 2006; Lydersen et al., 2003; Saloranta et al., 2009; Saloranta, 2006; Couture et al., 2014). It was therefore considered as a suitable 10 model for Lake Årungen.

\subsection{Inputs and outputs}

MyLake requires input of meteorological forcing, runoff volume and temperature, and fluxes of suspended inorganic particles and total phosphorus (TP) to model phosphorus and phytoplankton dynamics in the lake (Table 1). Meteorological data for daily 15 air temperature, global radiation, cloud cover, precipitation, relative humidity and wind speed were obtained from the nearby meteorological station located at the Norwegian University of Life Sciences $\left(59^{\circ} 39^{\prime} 37^{\prime \prime} \mathrm{N}, 10^{\circ} 46^{\prime} 54^{\prime \prime} \mathrm{E}\right)$. Time series of daily runoff volume, runoff water temperature, and fluxes of suspended inorganic particles and total phosphorus are available for the period 1994 to 2010 from the Skuterud moni20 toring station (Fig. 1) with a hydrovolumetric weir. The monitoring station is located at an inlet stream to Østensjøvann $\left(59^{\circ} 41^{\prime} 18^{\prime \prime} \mathrm{N}, 10^{\circ} 49^{\prime} 45^{\prime \prime} \mathrm{E}\right)$, a small lake of $0.4 \mathrm{~km}^{2}$ which drains into the Lake Årungen (Deelstra et al., 2007). Runoff from the other subcatchments was estimated by scaling up the Skuterud data. The up-scaling was based on previously determined flow and nutrient scaling factors that take into account dif25 ferences in area and land use between sub-catchments (Askilsrud, 2010). A separate MyLake model was set up for Lake Østensjøvann to account for the buffering effects of

Natural stochasticity

vs. management effort

A. T. Romarheim et al.

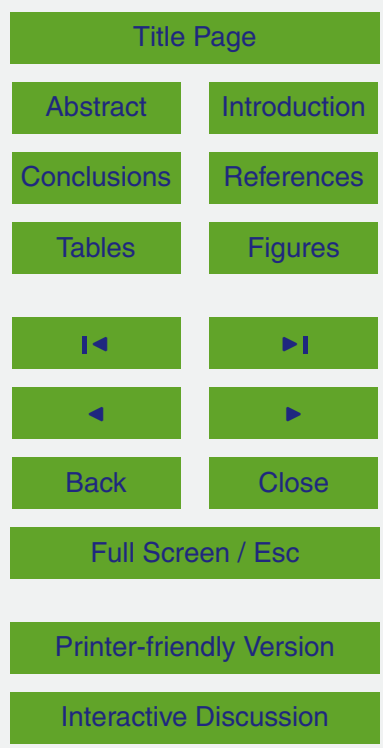

12494 
this lake in the largest sub-catchment of Lake Årungen. The simulated water properties of Lake Østensjøvann were combined with runoff from the other sub-catchments as an estimate of the total runoff to Lake Årungen.

Six variables including whole-lake average TP pool, mean surface chlorophyll con5 centration, light attenuation coefficient, thermocline depth, epilimnion temperature, and ice thickness were calculated from unprocessed model outputs (Table 1) in order to ease interpretation of the statistical analyses for scenario experiment described below.

\subsection{Model calibration}

Water temperature, TP, soluble reactive phosphorus (SRP), and chlorophyll a concentration from the deepest location in the lake were used to calibrate the model (Table 1). Vertical water temperature profile was continuously logged every hour at eight depths between 0.7 and $12.6 \mathrm{~m}$ by Hobo pendant temperature loggers (model 64K-UA-002-64; Onset Computer Corporation, Bourne, MA, USA) in the period from November 2008 to August 2010. Water samples for chemical and biological analyses were collected 15 with a modified Rüttner water sampler at seven depths twice a month or monthly ( $n=49$ ) from January 2008 to September 2010. TP, SRP and chlorophyll a were determined spectrophotometrically (UV-VIS Spectrophotometer UV-1201, Shimadzu, Kyoto, Japan).

We deployed the Markov chain Monte Carlo (MCMC) method (Andrieu et al., 2003) to calibrate the model. The calibration consisted of two stages. The first MCMC calibration stage involved three physical parameters (see Table 2) that only affect heat dynamics, in particular thermocline depth. This first calibration was run against daily temperature measurements, using 2000 MCMC steps with the first 1000 for burn-in. The second MCMC calibration stage involving eight parameters (see Table 2) that affect phospho25 rus and chlorophyll dynamics, but not temperature, was run against measurements of TP, SRP, and chlorophyll $a$ in 30000 MCMC steps with the first 10000 for burn-in. For these MCMC applications, convergence was monitored visually. Linear interpolation was used to match model outputs on a $0.5 \mathrm{~m}$ vertical grid to the actual measurement 12495

\section{HESSD}

11, 12489-12518, 2014

Natural stochasticity

vs. management effort

A. T. Romarheim et al.

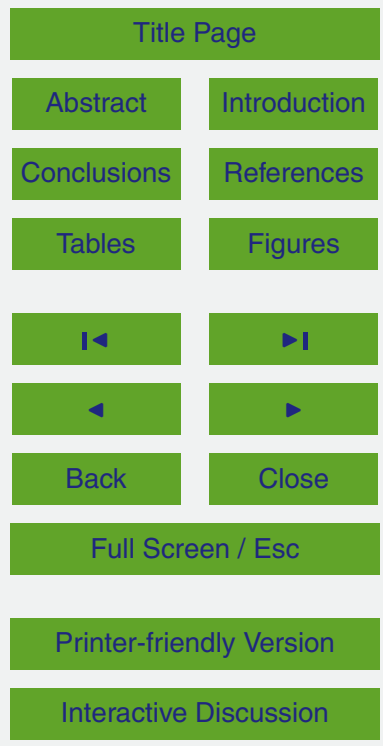


depths. Although it was not used directly during the MCMC calibration, model goodness of fit was informally assessed by root mean square error (RMSE). The medians of the posterior parameter distributions generated from both stages of the MCMC calibrations were used for the scenarios experiments described in the following.

\section{2.5 The variance-based method for disentangling confounding factors}

The model was run under six scenarios for nutrient loading and weather in order to quantify the respective impacts of weather variation and loading conditions on phosphorus and phytoplankton dynamics (Table 3). These scenarios were based on input combination of observed data (original data, 1994-2010) and synthetic data, where day of the year. Synthetic data repeats the calculated mean year with 365 days sixteen times. The 29 February is removed in year-to-year mean calculation, and 28 February was repeated to account for the 29 in leap years.

This approach combines the actual forcing data for some variables together with 15 average year data for the other forcing data variables. Comparing such a synthetic scenario against the scenario using full actual forcing data elucidates importance of year-to-year variation of the second set of variables. For example, scenario $C$ (repeated average-year runoff) will necessarily have lower year-to-year variation $(n=16)$ in output variables compared with scenario A (full original data) (Table 3); the difference in 20 the scenario input (i.e. runoff input) accounts for the reduction in the year-to-year varition in the output variables. By examining which output variables are most reduced in year-to-year variation among all output variables, we obtain crucial information on the importance of runoff forcing data in the output. Thus we achived the the goal of the present study, namely disentangling the relative imporantce of year-to-year variaand average-year forcing data were derived from the study conducted by Jöhnk et al. (2008), in which the authors assessed the relative importance of various meteorological variables (air temperature, cloudiness, wind speed) in affecting various lake responses

\section{HESSD}

11, 12489-12518, 2014

Natural stochasticity

vs. management effort

A. T. Romarheim et al.

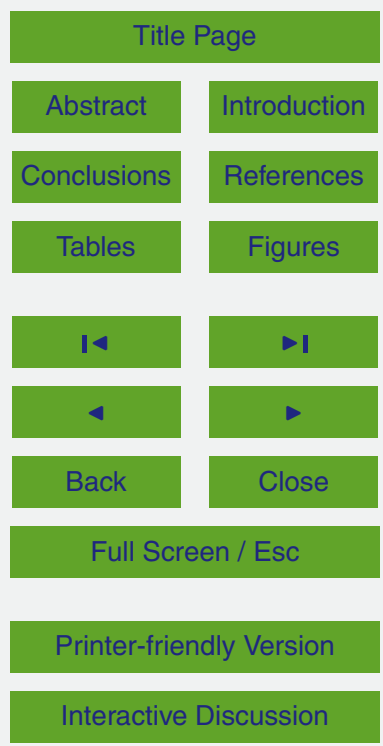


such as water temperature and albal cell counts of 3 phytoplankton groups. The present study compares standard deviation of the 16 years of simulation outputs for each day of year for 6 output variables among several sceniarios.

\subsection{Post-simulation methods}

5 A two-way analysis of variance (ANOVA) was run on the 16 years of water year based simulation statistics (water year mean, see Table 1), among scenarios $A, B, C$ and $D$ (two weather factors by two loading factors, see Table 3). All annual averages are computed over the period from 1 October to 30 September, commonly used in Europe to refer on a hydrological year, or a water year (Otnes and Ræstad, 1978). Since treatment contrasts are nested within water years we factored out the between-year variances to gain a greater power in the statistical tests. Principal component analysis (PCA) was used to explore the relationships between meteorological and land-related forcing and their relevance for the simulated lake response. Four water years with extreme PCA scores were selected for studying contrasting lake responses in closer details.

\section{Results}

\subsection{Calibration}

The simulated water temperature and thermal dynamics of the lake were in agreement with the lake observed data. Observed water temperature measurements were well predicted by simulation and the RMSE was less than $2^{\circ} \mathrm{C}$ at all lake depths (Fig. 2).

After the water temperature calibration, parameters controlling TP, SRP, and chlorophyll a were calibrated against observed data for the period from January 2008 to September 2010. The epilimnion TP, SRP, and chlorophyll a concentrations were well predicted by the model, although their prediction was less successful than the prediction of the water temperature. The TP and SRP were better predicted by the model in

shallower water than in deeper water whereas the chlorophyll a showed the opposite

\section{HESSD}

$11,12489-12518,2014$

Natural stochasticity

vs. management effort

A. T. Romarheim et al.

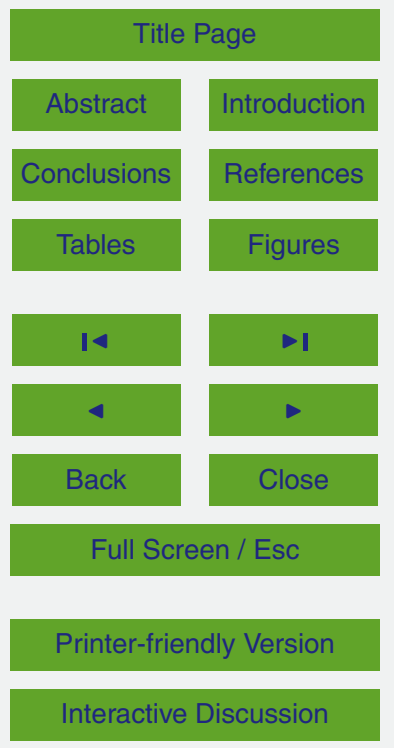

Interactive Discussion 
pattern. In general, the model simulated well TP and SRP, although both phosphorus forms were overestimated in early spring and autumn at shallow depths, while underestimated in bottom water. Simulated SRP concentrations were also somewhat higher than observed in winters. However, the simulation succeeded in showing a decreas5 ing trend of lake phosphorus in spring and midsummer, and in mimicking its increase during the autumn mixing of water. Although the simulated chlorophyll concentrations were lower than the measured values, the model was able to predict seasonal variation in phytoplankton primary production and to simulate high phytoplankton biomasses in the lake epilimnion during midsummer.

\subsection{Variability in forcing data}

Inter-annual variation was expressed as the standard deviation in inputs and outputs between the years. All weather inputs varied between years (Fig. 3), with air temperature and global radiation having the strongest seasonal pattern in inter-annual variation (i.e. greater 16 year variation as compared to year-to-year variation on a day-of-year basis). The inter-annual variation in air temperature was strongest in the winter period, whereas global radiation varied most during the summer months. The variation in cloud cover, precipitation and relative humidity was generally similar across seasons. The year-to-year variation for precipitation was particularly high in December and in the period from July to September, the latter reflecting extreme precipitation events. Wind speed varied most in winters.

Runoff input data on water flow and concentrations of TP and suspended matter all varied seasonally and between years. The variation in runoff volume was greatest in the period from October to May. No clear seasonal pattern in the degree of variability could be found for suspended matter and TP fluxes, although the variation of TP influx
HESSD

$11,12489-12518,2014$

Natural stochasticity

vs. management effort

A. T. Romarheim et al.

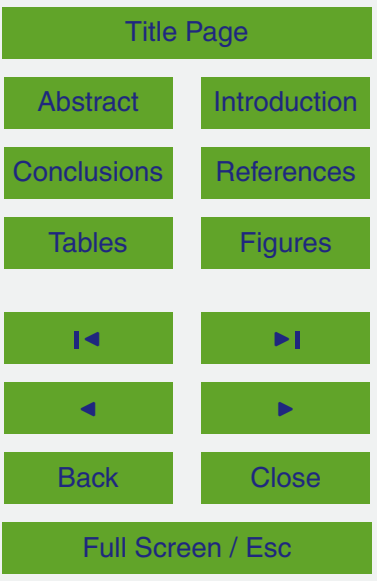

Printer-friendly Version

Interactive Discussion 


\subsection{Variability in simulation outputs: disentangled significance of confounding factors}

Differences in year-to-year variation among the scenarios (Fig. 4) and the annual statistics (Table 4) illustrate the seasonal influence of the external forcing on the thermal 5 regime and the phosphorus and phytoplankton dynamics in the lake. The lake responded differently between years; all simulated outputs, except ice thickness, showed large variation in the beginning and at the end of the phytoplankton growing season (Fig. 4). All simulated output variables were influenced by external forcing to some extent as they varied inter-annually for all model scenarios. Ice thickness was significantly affected by weather $(P<0.001)$ as both air temperature and winter precipitation highly contributed to its variation between years (Table 4; Fig. 4). The variation in thermocline depth in May and October was well revealed by the model, and seemed to be equally dependent on weather and loading. The epilimnion temperature during the whole growing season was largely controlled by weather. The TP content in the lake 15 was most variable in the period from November to January, and in April and July. Loading could mostly explain the inter-annual TP variation in the lake, whereas precipitation contributed to TP variation only in the spring, and air temperature only during the winter period. Loading was the overall most important factor in controlling the light attenuation coefficient $(P<0.001)$ and surface chlorophyll concentration $(P<0.001)$. Weather seemed to be important in controlling chlorophyll and light attenuation in early spring whereas loading was the most important factor controlling the both variables from June to September.

The years 1996, 2000, 2006 and 2007 were the four most extreme years determined on the basis of the PCA analysis (Fig. 5). The year 1996 was characterized by relatively low average annual air temperature, a thin cloud cover and low precipitation, which resulted in low epilimnion water temperature, short lasting thermocline, low runoff volume, and TP in the lake. The year 2007 represents an opposite to 1996, regarding weather characteristics and resulting model simulation with relatively high

\section{HESSD}

$11,12489-12518,2014$

Natural stochasticity

vs. management effort

A. T. Romarheim et al.

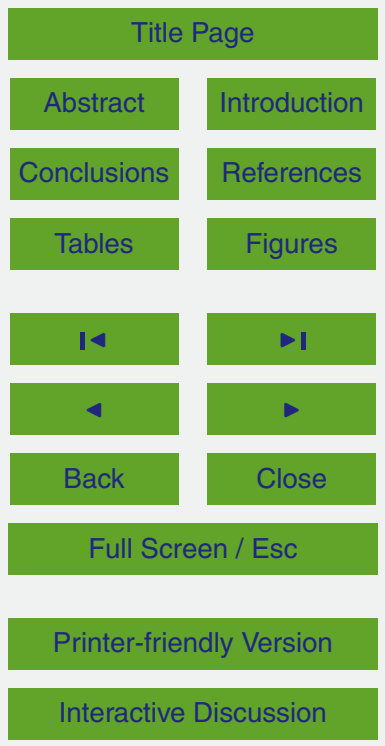


average annual air temperature and precipitation. Increase in wind speed, decrease in air temperature, and decrease in precipitation coincided with increase in ice thickness and glocal radiation, such as in 2003-2006, 2009, and 2010. These weather conditions resulted in lower suspended inorganic particles and TP in runoff which coincided with

5 lower surface chlorophyll concentration and light attenuation. The year 2006 was identified as the extreme during this period, with a cold winter followed by a warm summer. In contrast, the year 2000 was characterized as a year with less global radiation, lower summer air temperature, and higher wind speed, but with higher winter temperature and precipitation. Such weather conditions pronounced higher TP and suspended par10 ticle in runoff compared with an average year, resulting in a high surface chlorophyll concentration and lower water transparency.

\section{Discussion}

\subsection{Year-to-year variability in lake responses}

Year-to-year weather variations, as well as the influence of catchment land-use and 15 hydrology, hinder our understanding of how individual stressors may affect the lake response (Blenckner, 2005). Our model experiment, which involved the input of weather and loading data for 16 years, was able to outline the respective importance of year-toyear variation in external forcing on physical, chemical and biological response in Lake Årungen. The combination of high forcing variability and high lake response sensitivity made the inter-annual variation most dramatically expressed in spring and autumn.

Air temperature, precipitation, and wind speed are the principal factors influencing freshwater ecosystems in a changing climate (Nickus et al., 2010). The lake thermal regime was to a large extent affected by weather conditions, particularly by air temperature. Variable winter air temperatures were an important factor influencing the heating and mixing processes during spring. A dynamic physical environment at the beginning of the growing season has considerable influence on the phytoplankton community

\section{HESSD}

$11,12489-12518,2014$

Natural stochasticity

vs. management effort

A. T. Romarheim et al.

\section{Title Page}

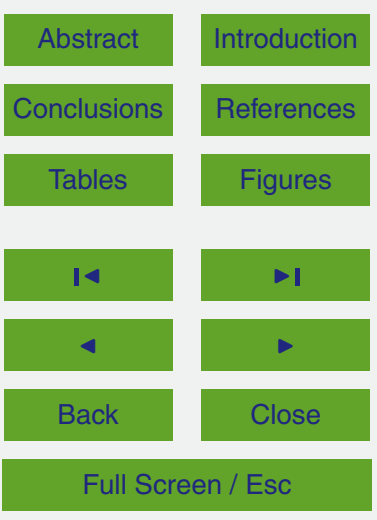

Printer-friendly Version

Interactive Discussion 
structure and its dynamics (Weyhenmeyer et al., 2002). For example, increased surface water temperatures in the English Lake District (George et al., 2007) and incomplete water mixing in Lake Constance (Straile et al., 2003a) have earlier been associated with mild winters. High inter-annual variation in winter air temperatures in Lake Årun5 gen was reflected in the simulated ice thickness and phenology of ice formation, with ice forming in December-January and disappearing in March-April. Also in other lake studies, thinner and shorter ice cover has been related to mild winters (Nickus et al., 2010). In this study, the time of thermocline formation varied among years by more than one month, from mid-April to mid-May. The large year-to-year variation in thermocline 10 depth and duration could lead to changes in temperature, light, and nutrient condition in the lake, which further shape the phytoplankton community and determine its total biomass (Padisák et al., 2010; Zohary et al., 2010). For instance, early disappearance of diatoms and high development of cyanobacteria in European lakes has been related to winter warming and increased water temperature (Weyhenmeyer et al., 2002). Fur15 thermore, increase in water stability favours the buoyant phytoplankton species such as bloom forming cyanobacteria (Reynolds et al., 1983; Winder and Hunter, 2008).

Year-to-year variation in phosphorus content in the lake was highly influenced by nutrient loading. This indicates that the external nutrient supply remains an important source of phosphorus in the lake. Although the changes in nutrient loading are primarily linked to anthropogenic activities in the catchment, in particular to practices in agriculture, the short-term variations in weather and runoff can also influence the nutrient supply from external sources. Lake Årungen is surrounded by agricultural land, and is especially sensitive to variable weather conditions that promote nutrient loading from the catchment. More precisely, air temperature and rainfall frequency and intensity affect the runoff and the soil erosion pattern, particularly during the winter period. Increase in winter temperatures occuring together with frequent freezing and melting events increases the risk of erosion, which again will increase the nutrient loading to the lake (Bechmann et al., 2005; Jeppesen et al., 2009; Nõges et al., 2007). Although not statistically demonstrated in the present study, the indirect impacts of weather conditions

\section{HESSD}

11, 12489-12518, 2014

Natural stochasticity

vs. management effort

A. T. Romarheim et al.

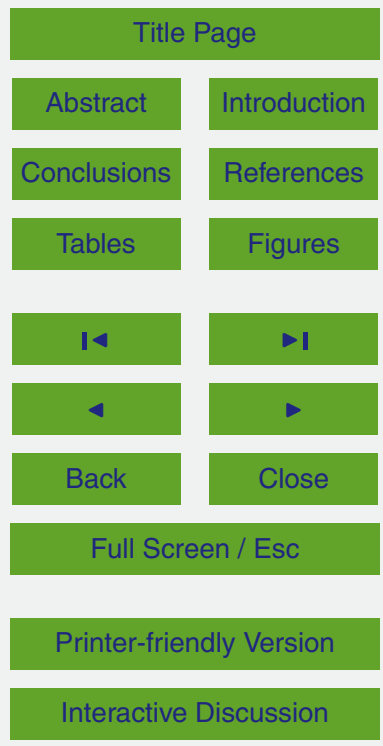


on discharge may still be important in regulating the nutrient dynamics. Variable winter weather conditions, and the time of ice out were most important cause of year-to-year variable phosphorus content in the period from November to January and in April in Lake Årungen. Enhanced phosphorus concentrations in streams during winter, and 5 high phosphorus loading in early spring, both contribute to the total lake phosphorus concentration during the following summer in two Norwegian lakes with agricultural catchments (Bechmann et al., 2005). In addition, the variation in summer TP content could also be the result of between-year variation in rainfall, especially due to extreme precipitation events as observed for particular days in July. High inter-annual varia10 tion in TP content can consequently result in variable phytoplankton biomass between years.

Phytoplankton biomass and light were significantly affected by loading, although atmospheric forcing also contributed to their inter-annual variation in the lake. The effect of loading was pronounced during the whole algal growing season, whereas weather

had the strongest effect in early spring and from mid-August to the end of the growing season. Thermal stratification is highly dependent on weather and may further influence water mixing as well as light and nutrient regimes, which are important in controlling the phytoplankton dynamics (Padisák et al., 2010; Zohary et al., 2010). Similar pattern of year-to-year variation in water temperature, chlorophyll concentration, and light attenuation indicates a close relationship between these variables. Higher air temperature promoted higher water temperature and higher stability of the thermal stratification which enhanced phytoplankton production of bloom forming cyanobacteria (Reynolds et al., 1983; Weyhenmeyer et al., 2002). Runoff and soil erosion, caused by intense precipitation and frequent melting of snow and ice during mild winters, affect eutrophication and water turbidity (Bechmann et al., 2005; Jeppesen et al., 2009). Thus light may limit phytoplankton growth more than nutrients in highly turbid lakes such as Lake Årungen (Dokulil, 1994). Reduced light availability may be crucial for the competitive success of cyanobacteria which are functionally adapted to low light conditions (Litchman, 1998). Particularly high dominance of cyanobacteria has been observed in the

\section{HESSD}

$11,12489-12518,2014$

Natural stochasticity

vs. management effort

A. T. Romarheim et al.
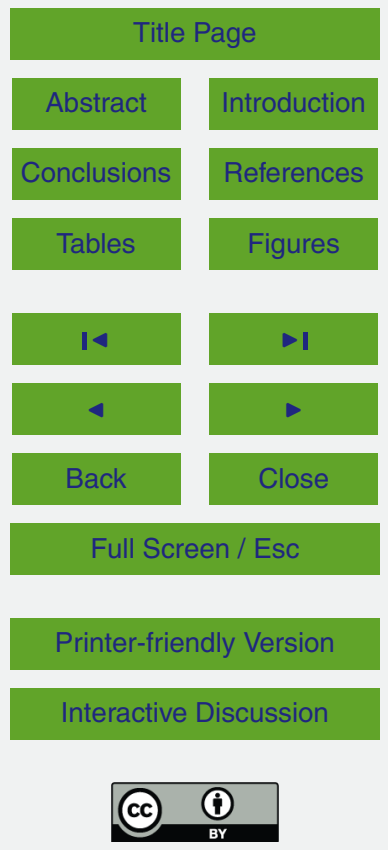
Lake Årungen after mild winters followed by low light conditions in spring (Romarheim et al., unpublished). Therefore, additional measures to control soil erosion may need to be implemented in water management, not only to reduce the supply of nutrients, but also to avoid low water transparency which may favour development of potentially toxic 5 cyanobacteria.

\subsection{Implications for lake management}

According to our PCA analysis, most of the 1990s were categorized by winters with higher temperatures and more rainfall. The mild winters were related to a positive North Atlantic Oscillation (NAO) phase which has been shown to strongly influence physicochemical and biological responses in western European lakes (George et al., 2007; Straile et al., 2003b; Weyhenmeyer et al., 2002). The effect of climate condition on water ecosystems, however, should be considered individually as the lake response is also determined by the lake's geographical position, landscape topography, and the lake's morphometry and mixing regime (Nickus et al., 2010). Our model experiment indicated that greater inflow of suspended matter and phosphorus to the lake Årungen is expected after mild winters with high precipitation. Consequently, higher chlorophyll concentrations and greater light attenuation were predicted after mild and wet winters such in the year of 2000 . Mild winters may thus counteract measures aimed to reduce external nutrient supply and to control phytoplankton production in cold temperate lakes, appearing to have contributed to little improvement. On the contrary, cold winters were related to thicker ice layer, less inflow of suspended matter and phosphorus, and low chlorophyll and light attenuation. This was consistent with the observed increase in water transparency and reduction of phytoplankton biomass, particularly of cyanobacteria, in Lake Årungen after the cold winter in 2010 (Romarheim et al., un25 published). Special attention must therefore be given to management practices, which should minimize the use of fertilizers and reduce the risk of nutrient runoff and soil erosion, especially in areas that drains directly into the lake. Higher annual air temperature coincided with warmer epilimnion, shallower thermocline and extended summer 12503
HESSD

$11,12489-12518,2014$

Natural stochasticity

vs. management effort

A. T. Romarheim et al.

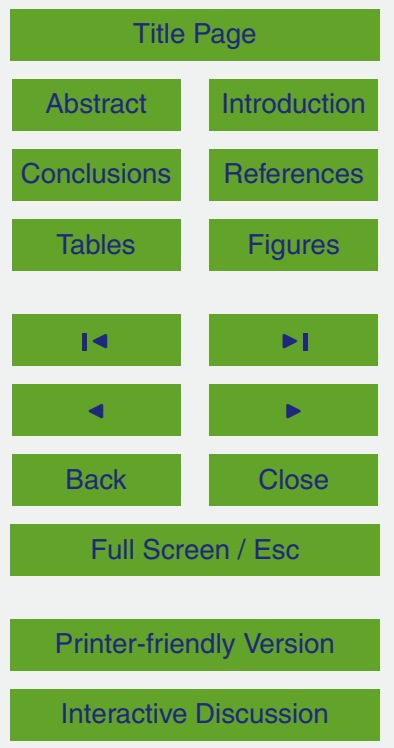


stratification such as for the year of 2007. In addition, high annual precipitation and runoff volume, particularly in summer, coincided with warmer years.

Globally, all years in the period from 1995 to 2006, with exception of 1996, were among the warmest since 1850 (Trenberth et al., 2007). Likewise, the year 1996 5 was characterised with low average annual air temperature in our model experiment. Lower annual air temperature and low rainfall in 1996 led to low epilimnion temperature, and a deep and short lasting thermocline. According to future climate predictions for Scandinavia, warmer winters and increased winter precipitation are expected in south-eastern Norway (Hanssen-Bauer et al., 2005). If so, we should also expect 10 more intensive soil erosion, higher phosphorus loading, lower water transparency, and greater phytoplankton biomasses, primarily of cyanobacteira in the lakes. Global climate changes and inter-annual variations in the local weather both directly, and indirectly through an impact on the catchment, influence the physicochemical and biological processes in lakes. Therefore, the effect of climate should be considered in future decision-making concerning water management.

Acknowledgements. We thank the Norwegian Institute for Agricultural and Environmental Research (Bioforsk) for providing runoff data from Skuterud monitoring station. We also thank Johnny Kristiansen at the Department of Environmental Sciences, Norwegian University of Life Sciences for excellent assistance during the field and laboratory work. PURA, an EU water 20 framework directive project within the Follo, Oslo region, Norway, is also thanked for financial support during the study. This work was partly carried out with support from the Research Council of Norway (Project Eutropia 190028/S30). We thank Tuomo Saloranta for providing an example code for parameter estimation. The calculations presented in this manuscript was made possible with freely available software, in particular, Octave and R, and we are grateful possible with the Open Access Publication Fund at the University of Oslo.

HESSD

$11,12489-12518,2014$

Natural stochasticity

vs. management effort

A. T. Romarheim et al.

Title Page

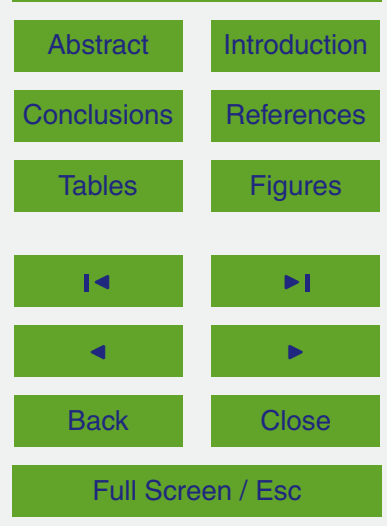

Printer-friendly Version

Interactive Discussion 


\section{References}

Andrieu, C., de Freitas, N., Doucet, A., and Jordan, M.: An introduction to MCMC for machine learning, Mach. Learn., 50, 5-43, 2003. 12495

Arheimer, B., Andréasson, J., Fogelberg, S., Johnsson, H., Pers, C. B., and Persson, K.: Climate 5 change impact on water quality: model results from southern Sweden, Ambio, 34, 559-566, 2005. 12492

Askilsrud, H.: Nutrient Input to Lake Årungen: Assessment of Data Availability to Run the MyLake Model, M.S. Thesis, Norwegian University of Life Sciences, Ås, Norway, 2010. 12494

Bailey-Watts, A. E. and Kirika, A.: Poor water quality in Loch Leven (Scotland) in 1995 in spite of reduced phosphorus loadings since 1985: the influences of catchment management and inter-annual weather variation, Hydrobiologia, 403, 135-151, doi:10.1023/A:1003758713050, 1999. 12491

Bechmann, M., Berge, D., Eggestad, H., and Vandsemb, S.: Phosphorus transfer from agricultural areas and its impact on the eutrophication of lakes - two long-term integrated studies from Norway, J. Hydrol., 304, 238-250, 2005. 12501, 12502

Blenckner, T.: A conceptual model of climate-related effects on lake ecosystems, Hydrobiologia, 533, 1-14, doi:10.1007/s10750-004-1463-4, 2005. 12500

Blenckner, T., Adrian, R., Livingstone, D. M., Jennings, E., Weyhenmeyer, G. A., George, D. G., Jankowski, T., Järvinen, M., Aonghusa, C. N., Nõges, T., Straile, D., and Teubner, K.: Largescale climatic signatures in lakes across Europe: a meta-analysis, Global Change Biol., 13, 1314-1326, doi:10.1111/j.1365-2486.2007.01364.x, 2007. 12491

Borch, H., Yri, A., Løvstad, Ø., and Turtumøygard, S.: Titaksplan for Årungen (Abatement measures for Lake Årungen, in Norwegian), Tech. Rep. 52, Norwegian Institute for Agricultural and Environmental Research, Ås, Norway, 2007. 12492

Couture, R.-M., Tominaga, K., Starrfelt, J., Moe, S. J., Kaste, Ø., and Wright, R. F.: Modelling phosphorus loading and algal blooms in a Nordic agricultural catchment-lake system under changing land-use and climate, Environ. Sci. Proces. Imp., 16, 1588-1599, doi:10.1039/c3em00630a, 2014. 12494

Deelstra, J., Ludvigsen, G. H., Pengerud, A., Eggestad, H. O., Tveiti, G., and Øygarden, L.: Jord- og vannovervåking i landbruket (JOVA): Skuterudbekken (Monitoring of soil and water in agriculture at Skuterud Stream, in Norwegian), Tech. Rep. 118, Norwegian Institute for Agricultural and Environmental Research, Ås, Norway, 2007. 12494
HESSD

11, 12489-12518, 2014

Natural stochasticity

vs. management effort

A. T. Romarheim et al.

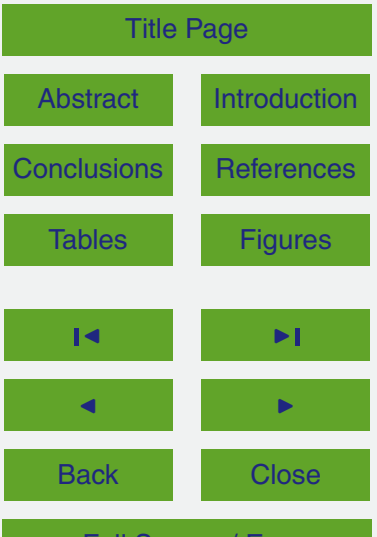

Full Screen / Esc

Printer-friendly Version

Interactive Discussion 
Dokulil, M. T.: Environmental control of phytoplankton productivity in turbulent turbid systems, Hydrobiologia, 289, 65-72, doi:10.1007/BF00007409, 1994. 12502

Ensby, S., Borgstrøm, R., Langeland, G., Rosland, F., and Sanni, S.: Årungen: tilstand, aktuelle sanerings- og restaureringstiltak: rapport utarbeidet på grunnlag av tverrfaglig forskn-

5 ingsaktivitet i perioden 1980-1983 (State, remediation and restoration measures in Lake Årungen: report based on interdisciplinary research in 1980-1983, in Norwegian), Institutt for Georessurs- og Forurensningsforskring, Ås, Norway, 1984. 12492

George, G., Hurley, M., and Hewitt, D.: The impact of climate change on the physical characteristics of the larger lakes in the English Lake District, Freshwater Biol., 52, 1647-1666, doi:10.1111/j.1365-2427.2007.01773.x, 2007. 12491, 12501, 12503

Hanssen-Bauer, I., Achberger, C., Benestad, R. E., Chen, D., and Forland, E. J.: Statistical downscaling of climate scenarios over Scandinavia, Clim. Res., 29, 255-268, doi:10.3354/cr029255, 2005. 12504

Huber, V., Adrian, R., and Gerten, D.: Phytoplankton response to climate warming modified by 15 trophic state, Limnol. Oceanogr., 53, 1-13, doi:10.4319/lo.2008.53.1.0001, 2008. 12491

Jeppesen, E., Søndergaard, M., Jensen, J. P., Havens, K. E., Anneville, O., Carvalho, L., Coveney, M. F., Deneke, R., Dokulil, M. T., Foy, B., Gerdeaux, D., Hampton, S. E., Hilt, S., Kangur, K., Köhler, J., Lammens, E. H., Lauridsen, T. L., Manca, M., Miracle, M. R., Moss, B., Nõges, P., Persson, G., Phillips, G., Portielje, R., Romo, S., Schelske, C. L., Straile, D., Tatrai, I., Willén, E., and Winder, M.: Lake responses to reduced nutrient loading - an analysis of contemporary long-term data from 35 case studies, Freshwater Biol., 50, 1747-1771, doi:10.1111/j.1365-2427.2005.01415.x, 2005. 12491

Jeppesen, E., Meerhoff, M., Jacobsen, B. A., Hansen, R. S., Søndergaard, M., Jensen, J. P., Lauridsen, T. L., Mazzeo, N., and Branco, C. W. C.: Restoration of shallow lakes by nutrient control and biomanipulation - the successful strategy varies with lake size and climate, Hydrobiologia, 581, 269-285, doi:10.1007/s10750-006-0507-3, 2007a. 12491

Jeppesen, E., Søndergaard, M., Meerhoff, M., Lauridsen, T. L., and Jensen, J. P.: Shallow lake restoration by nutrient loading reduction - some recent findings and challenges ahead, in: Shallow Lakes in a Changing World, edited by: Gulati, R. D., Lammens, E., Pauw, N. D., and Donk, E. V., Developments in Hydrobiology, no. 196, Springer Netherlands, Dordrecht, the Netherlands, 239-252, 2007b. 12491

\section{HESSD}

$11,12489-12518,2014$

\section{Natural stochasticity \\ vs. management effort \\ A. T. Romarheim et al.}

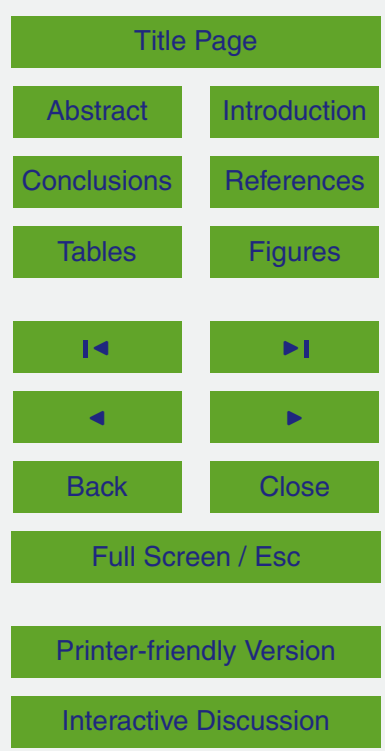


Jeppesen, E., Kronvang, B., Meerhoff, M., Sondergaard, M., Hansen, K. M., Andersen, H. E., Lauridsen, T. L., Liboriussen, L., Beklioglu, M., Ozen, A., and Olesen, J. E.: Climate change effects on runoff, catchment phosphorus loading and lake ecological state, and potential adaptations, J. Environ. Qual., 38, 1930-1941, 2009. 12491, 12501, 12502

5 Jöhnk, K. D., Huisman, J., Sharples, J., Sommeijer, B., Visser, P. M., and Stroom, J. M.: Summer heatwaves promote blooms of harmful cyanobacteria, Global Change Biol., 14, 495-512, doi:10.1111/j.1365-2486.2007.01510.x, 2008. 12493, 12496

Kankaala, P., Huotari, J., Peltomaa, E., Saloranta, T., and Ojala, A.: Methanotrophic activity in relation to methane efflux and total heterotrophic bacterial production in a stratified, humic, boreal lake, Limnol. Oceanogr., 51, 1195-1204, doi:10.4319/lo.2006.51.2.1195, 2006. 12494

Litchman, E.: Population and community responses of phytoplankton to fluctuating light, Oecologia, 117, 247-257, doi:10.1007/s004420050655, 1998. 12502

Løvstad, Ø. and Krogstad, T.: Årungen 1992: eutrofiering, plantenæringsstoffer og blågrønnalger (Lake Årungen 1992: eutrophication, plant nutrients and blue-green algae, in Norwegian), Institutt for Jordfag, Norges Landbrukshøgskole, Ås, Norway, 1993. 12492

Lydersen, E., Aanes, K. J., Andersen, S., Andersen, T., Brettum, P., Bækken, T., Lien, L., Lindstrøm, E. A., Løvik, J. E., Mjelde, M., Oredalen, T. J., Lyche, A. S., Ropmstad, R., Rørslett, B., and Saloranta, T.: THERMOS-projektet: Fagrapport 1998-2002 (THERMOS Project technical report 1998-2002, in Norwegian), Tech. Rep. 4720, Norwegian Institute for Water Research, Oslo, Norway, 2003. 12494

Mooij, W. M., Trolle, D., Jeppesen, E., Arhonditsis, G., Belolipetsky, P. V., Chitamwebwa, D. B. R., Degermendzhy, A. G., DeAngelis, D. L., Domis, L. N. D. S., Downing, A. S., Elliott, J. A., Fragoso, C. R., Gaedke, U., Genova, S. N., Gulati, R. D., Hakanson, L., Hamilton, D. P., Hipsey, M. R., 't Hoen, J., Huelsmann, S., Los, F. H., Makler-Pick, V., Petzoldt, T., Prokopkin, I. G., Rinke, K., Schep, S. A., Tominaga, K., Van Dam, A. A., Van Nes, E. H., Wells, S. A., and Janse, J. H.: Challenges and opportunities for integrating lake ecosystem modelling approaches, Aquat. Ecol., 44, 633-667, doi:10.1007/s10452-010-9339-3, 2010. 12492

Nickus, U., Bishop, K., Erlandsson, M., Evans, C. D., Forsius, M., Laudon, H., Livingstone, D. M., Monteith, D., and Thies, H.: Direct impacts of climate change on freshwater ecosystems, in: Climate Change Impacts on Freshwater Ecosystems, edited by: Kernan, R., Battarbee, R. W., and Moss, B., Wiley-Blackwell, Chichester, West Sussex, UK, 38-64, 2010. 12500, 12501, 12503 
Nõges, P., Kägu, M., and Nõges, T.: Role of climate and agricultural practice in determining matter discharge into large, shallow Lake Võrtsjärv, Estonia, in: Eutrophication of Shallow Lakes with Special Reference to Lake Taihu, China, edited by: Qin, B., Liu, Z., and Havens, K., Developments in Hydrobiology, no. 194, Springer Netherlands, Dordrecht, the Netherlands, 125-134, 2007. 12492, 12501

Otnes, J. and Ræstad, E.: Hydrologi i praksis, Ingeniørforlaget, Oslo, Norway, 1978. 12497

Padisák, J., Hajnal, É., Naselli-Flores, L., Dokulil, M. T., Nõges, P., and Zohary, T.: Convergence and divergence in organization of phytoplankton communities under various regimes of physical and biological control, Hydrobiologia, 639, 205-220, doi:10.1007/s10750-009-

$10 \quad$ 0021-5, 2010. 12501, 12502

Reynolds, C. S., Wiseman, S. W., Godfrey, B. M., and Butterwick, C.: Some effects of artificial mixing on the dynamics of phytoplankton populations in large limnetic enclosures, J. Plankton Res., 5, 203-234, doi:10.1093/plankt/5.2.203, 1983. 12501, 12502

Riley, M. J. and Stefan, H. G.: MINLAKE: a dynamic lake water quality simulation model, Ecol. Model., 43, 155-182, doi:10.1016/0304-3800(88)90002-6, 1988. 12494

Saloranta, T. M.: Highlighting the model code selection and application process in policy-relevant water quality modelling, Ecol. Model., 194, 316-327, doi:10.1016/j.ecolmodel.2005.10.031, 2006. 12494

Saloranta, T. M. and Andersen, T.: MyLake - a multi-year lake simulation model code suitable for uncertainty and sensitivity analysis simulations, Ecol. Model., 207, 45-60, 2007. 12493, 12494, 12511

Saloranta, T. M., Forsius, M., Jarvinen, M., and Arvola, L.: Impacts of projected climate change on the thermodynamics of a shallow and a deep lake in Finland: model simulations and Bayesian uncertainty analysis, Hydrol. Res., 40, 234-248, 2009. 12494

Schindler, D. W.: Evolution of phosphorus limitation in lakes, Science, 195, 260-262, 1977. 12491

Smith, V., Tilman, G., and Nekola, J.: Eutrophication: impacts of excess nutrient inputs on freshwater, marine, and terrestrial ecosystems, Environ. Pollut., 100, 179-196, 1999. 12491

Straile, D., Jöhnk, K., and Rossknecht, H.: Complex effects of winter warming on the 30 physicochemical characteristics of a deep lake, Limnol. Oceanogr., 48, 1432-1438, doi:10.4319/lo.2003.48.4.1432, 2003a. 12491, 12501
HESSD

$11,12489-12518,2014$

Natural stochasticity

vs. management

effort

A. T. Romarheim et al.

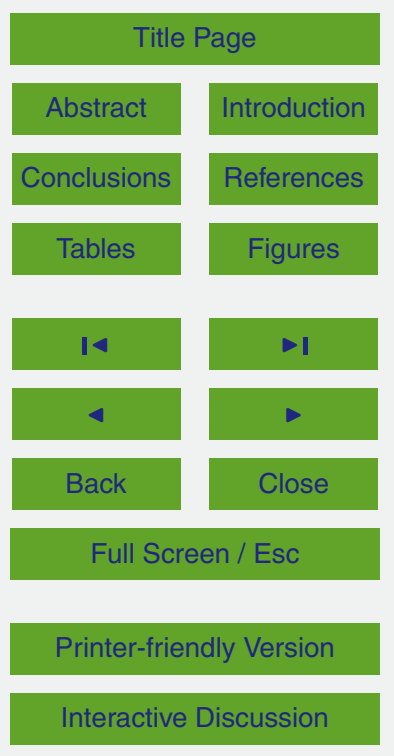


Straile, D., Livingstone, D. M., Weyhenmeyer, G. A., and George, D. G.: The response of freshwater ecosystems to climate variability associated with the North Atlantic Oscillation, in: The North Atlantic Oscillation: Climatic Significance and Environmental Impact, edited by: Hurrell, J. W., Kushnir, Y., Ottersen, G., and Visbeck, M., American Geophysical Union, Washington, D.C., USA, 263-279, 2003b. 12503

Tirok, K. and Gaedke, U.: The effect of irradiance, vertical mixing and temperature on spring phytoplankton dynamics under climate change: long-term observations and model analysis, Oecologia, 150, 625-642, 2007. 12491

Trenberth, K., Jones, P., Ambenje, P., Bojariu, R., Easterling, D., Klein Tank, A., Parker, D., Rahimzadeh, F., Renwick, J., Rusticucci, M., Soden, B., and Zhai, P.: Observations: surface and atmospheric climate change, in: Climate Change 2007: the Physical Science Basis, contribution of Working Group I to the Fourth Assessment Report of the Intergovernmental Panel on Climate Change, edited by: Solomon, S., Qin, D., Manning, M., Chen, Z., Marquis, M., Averyt, K., Tignor, M., and Miller, H., Cambridge University Press, 235-336, 2007. 12504

15 Ulén, B., Bechmann, M., Fölster, J., Jarvie, H. P., and Tunney, H.: Agriculture as a phosphorus source for eutrophication in the north-west European countries, Norway, Sweden, United Kingdom and Ireland: a review, Soil Use Manage., 23, 5-15, doi:10.1111/j.14752743.2007.00115.x, 2007. 12492

Weyhenmeyer, G. A., Adrian, R., Gaedke, U., Livingstone, D. M., and Maberly, S. C.: Response of phytoplankton in European lakes to a change in the North Atlantic Oscillation, Verh. Intern. Verein. Limnol., 28, 1436-1439, 2002. 12491, 12501, 12502, 12503

Whitehead, P. G., Wilby, R. L., Batterbee, R. W., Kernan, M., and Wade, A. J.: A review of the potential impacts of climate change on surface water quality, Hydrolog. Sci. J., 54, 101-123, doi:10.1623/hysj.54.1.101, 2009. 12491

Wilhelm, S. and Adrian, R.: Impact of summer warming on the thermal characteristics of a polymictic lake and consequences for oxygen, nutrients and phytoplankton, Freshwater Biol., 53, 226-237, doi:10.1111/j.1365-2427.2007.01887.x, 2008. 12491

Winder, M. and Hunter, D. A.: Temporal organization of phytoplankton communities linked to physical forcing, Oecologia, 156, 179-192, doi:10.1007/s00442-008-0964-7, 2008. 12501

30 Zohary, T., Padisák, J., and Naselli-Flores, L.: Phytoplankton in the physical environment: beyond nutrients, at the end, there is some light, Hydrobiologia, 639, 261-269, doi:10.1007/s10750-009-0032-2, 2010. 12501, 12502
HESSD

$11,12489-12518,2014$

Natural stochasticity

vs. management effort

A. T. Romarheim et al.

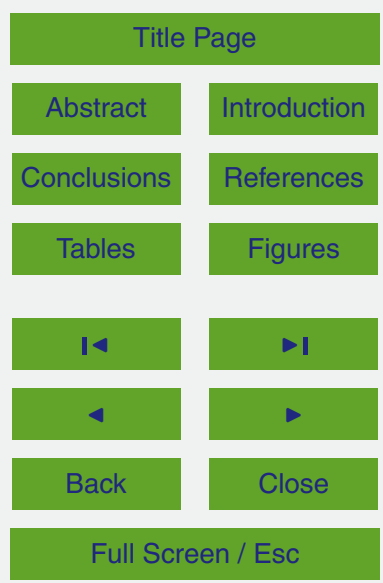

Printer-friendly Version

Interactive Discussion 
Table 1. Input and output data, and observed lake data for the calibration of the MyLake model and statistics for the ANOVA and PCA analyses.

\section{HESSD}

\section{$11,12489-12518,2014$}

\begin{tabular}{l} 
MyLake inputs \\
\hline Meteorological data $a^{\mathrm{a}, \mathrm{f}}$ \\
Air temperature \\
Global radiation \\
Cloud cover \\
Precipitation \\
Relative humidity \\
Wind speed \\
Runoff \\
Flow volume \\
Water temperature \\
Suspended matter flux \\
TP flux
\end{tabular}

MyLake outputs (selected)

Observed lake data

Calibration purpose ${ }^{\mathrm{a}}$

Statistics calculated for PCA

Global radiation ${ }^{\mathrm{C}}$

Cloud cover ${ }^{\mathrm{c}}$

Air temperature ${ }^{c}$

Wind speed ${ }^{\mathrm{C}}$

Precipitation $^{\mathrm{c}}$

Flow volume ${ }^{c}$

Winter air temperature ${ }^{\mathrm{d}, \mathrm{h}}$

Summer air temperature ${ }^{d, i}$

Winter precipitation, $\mathrm{d}$

Summer precipitation ${ }^{\mathrm{d}, \mathrm{i}}$

Suspended matter flux ${ }^{\mathrm{d}}$

TP flux ${ }^{\text {d }}$ (every $0.5 \mathrm{~m}$ by depth)

Water temperature

TP concentration

SRP concentration

Chlorophyll concentration

Statistics calculated for PCA

(volume weighted mean $0-3.0 \mathrm{~m}$ )

TP content

Mean surface chlorophyll

Light attenuation coeficient

Thermocline depth

Mean epilimnion temperature ${ }^{\mathrm{e}}$

\section{Calibration purpose \\ (at 7 depths) \\ Water temperature ${ }^{a}$ \\ TP concentration ${ }^{\mathrm{b}}$ \\ SRP concentration ${ }^{\mathrm{b}}$ \\ Chlorophyll a concentration ${ }^{b}$}

Ice thickness

${ }^{a}$ Daily data. ${ }^{b}$ Biweekly data. ${ }^{c}$ Annual mean. ${ }^{d}$ Water year basis (October through September). ${ }^{e}$ Volume weighted above thermocline depth. ${ }^{f}$ Inferred with data from Ås meteorological station. ${ }^{g}$ Inferred with data from Skuterud monitoring station and land use. ${ }^{h}$ December through March, mean. ${ }^{i}$ June through September, mean.

Natural stochasticity

vs. management effort

A. T. Romarheim et al.

Title Page

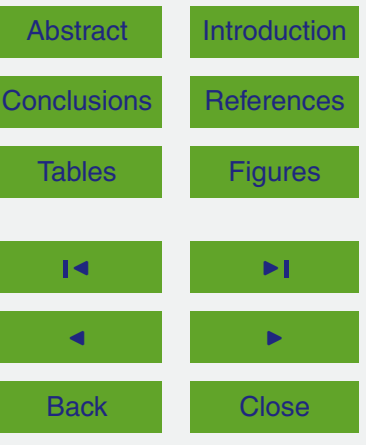

Full Screen / Esc

Printer-friendly Version

Interactive Discussion 
Table 2. Parameters involved in calibration based on two-stage Markov chain Monte Carlo (MCMC) application (first stage for three parameters using 2000 MCMC steps with 1000 steps for burn-in and second stage for eight parameters using 30000 MCMC steps with 10000 for burn-in). MyLake equation numbers refer to the original model description (Saloranta and Andersen, 2007). Median values were chosen among the posterior parameter distribution.

\begin{tabular}{|c|c|c|c|}
\hline Parameter & Value & Equation & Unit \\
\hline \multicolumn{4}{|l|}{ Physical parameters } \\
\hline Open-water vertical diffusion coefficient & $5.00 \times 10^{-1}$ & Eq. (10) & $\mathrm{m}^{2}$ day $^{-1}$ \\
\hline Wind sheltering coefficient & $7.96 \times 10^{-2}$ & Eq. (13) & - \\
\hline Minimum possible stability frequency & $9.31 \times 10^{-5}$ & Eq. (10) & $s^{-2}$ \\
\hline \multicolumn{4}{|l|}{ Biological and chemical parameters } \\
\hline PAR saturation level for photosynthesis & $2.04 \times 10^{-4}$ & Eq. (29) & mol quanta $\mathrm{m}^{-2} \mathrm{~s}^{-1}$ \\
\hline Particle resuspension mass transfer coefficient & $2.94 \times 10^{-5}$ & $\S 2.7$ & mday $^{-1}$, dry \\
\hline Settling velocity for suspended matter & 1.38 & Eq. (20) & $\mathrm{mday}^{-1}$ \\
\hline Settling velocity for chlorophyll & $7.31 \times 10^{-2}$ & Eq. (20) & $\mathrm{mday}^{-1}$ \\
\hline Specific mortality rate of phytoplankton & $1.86 \times 10^{-1}$ & Eq. (26) & day $^{-1}$ \\
\hline Max specific growth rate of phytoplankton & 1.76 & Eq. (27) & day $^{-1}$ \\
\hline $\begin{array}{l}\text { Half saturation inorganic phosphorus } \\
\text { concentration for Langmuir isotherm }\end{array}$ & $9.99 \times 10^{2}$ & Eq. (24) & $\mathrm{mg} \mathrm{m}^{-3}$ \\
\hline Saturation level for inorganic phosphorus isotherm & $4.96 \times 10^{4}$ & Eq. (24) & $\mathrm{mg} \mathrm{kg}^{-1}$ \\
\hline
\end{tabular}

Natural stochasticity vs. management effort

A. T. Romarheim et al. Title Page

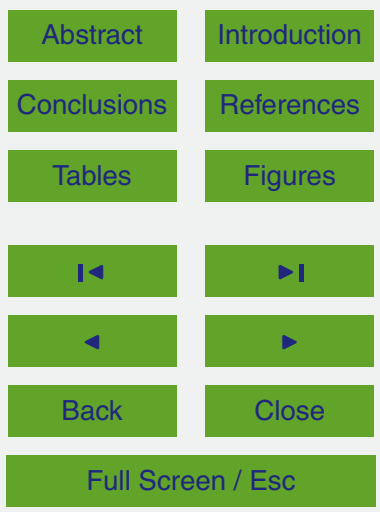

Printer-friendly Version

Interactive Discussion 
Table 3. Model scenarios. The scenarios comprise either original input data (denoted O), pseudo repeated average year based on 16 years of input data (denoted $\mathrm{R}$ ), or a combination of $\mathrm{O}$ and $\mathrm{R}$.

\begin{tabular}{lllllll}
\hline Model scenarios & A & B & C & D & Dt & Dp \\
\hline Model inputs & & & & & & \\
\hline Weather & & & & & & \\
Global radiation & $\mathrm{O}$ & $\mathrm{R}$ & $\mathrm{O}$ & $\mathrm{R}$ & $\mathrm{R}$ & $\mathrm{R}$ \\
Cloud cover & $\mathrm{O}$ & $\mathrm{R}$ & $\mathrm{O}$ & $\mathrm{R}$ & $\mathrm{R}$ & $\mathrm{R}$ \\
Relative humidity & $\mathrm{O}$ & $\mathrm{R}$ & $\mathrm{O}$ & $\mathrm{R}$ & $\mathrm{R}$ & $\mathrm{R}$ \\
Wind speed & $\mathrm{O}$ & $\mathrm{R}$ & $\mathrm{O}$ & $\mathrm{R}$ & $\mathrm{R}$ & $\mathrm{R}$ \\
Air pressure & $\mathrm{O}$ & $\mathrm{R}$ & $\mathrm{O}$ & $\mathrm{R}$ & $\mathrm{R}$ & $\mathrm{R}$ \\
Air temperature & $\mathrm{O}$ & $\mathrm{R}$ & $\mathrm{O}$ & $\mathrm{R}$ & $\mathrm{O}$ & $\mathrm{R}$ \\
Precipitation & $\mathrm{O}$ & $\mathrm{R}$ & $\mathrm{O}$ & $\mathrm{R}$ & $\mathrm{R}$ & $\mathrm{O}$ \\
\hline Runoff & & & & & & \\
Flow volume & $\mathrm{O}$ & $\mathrm{O}$ & $\mathrm{R}$ & $\mathrm{R}$ & $\mathrm{R}$ & $\mathrm{R}$ \\
Suspended matter flux & $\mathrm{O}$ & $\mathrm{O}$ & $\mathrm{R}$ & $\mathrm{R}$ & $\mathrm{R}$ & $\mathrm{R}$ \\
Inflow water temperature & $\mathrm{O}$ & $\mathrm{O}$ & $\mathrm{R}$ & $\mathrm{R}$ & $\mathrm{R}$ & $\mathrm{R}$ \\
TP flux & $\mathrm{O}$ & $\mathrm{O}$ & $\mathrm{R}$ & $\mathrm{R}$ & $\mathrm{R}$ & $\mathrm{R}$ \\
\hline
\end{tabular}

\section{HESSD}

$11,12489-12518,2014$

Natural stochasticity

vs. management

effort

\section{A. T. Romarheim et al.}

\section{Title Page}

Abstract

Introduction

Conclusions References

Tables

Figures

14

4

Back

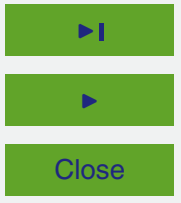

Full Screen / Esc

Printer-friendly Version

Interactive Discussion 
Natural stochasticity

vs. management

effort

Table 4. Summary results for six two-factor within-subject ANOVA $(n=16 \times 2 \times 2)$. Significance of additive and interactive effects of weather (two levels, original $O$ or repeated average $R$ ) and loading (two levels, original $\mathrm{O}$ or repeated average $\mathrm{R}$ ) inputs on the six selected model outputs are shown using $P$ value. High $P$ values for interactive effects for all six tests indicate pure additive two-factor model and test for each factor separately. $P$ values below 0.05 indicate significant differences between corresponding sample means.

\begin{tabular}{|c|c|c|c|}
\hline Model outputs & W & L & $W \times L$ \\
\hline Ice thickness, $\mathrm{m}$ & $<0.001$ & 0.839 & 0.560 \\
\hline Thermocline depth, $\mathrm{m}$ & 0.281 & 0.218 & 0.398 \\
\hline Epilimnion temperature, ${ }^{\circ} \mathrm{C}$ & 0.014 & 0.135 & 0.771 \\
\hline TP content, kg & 0.365 & 0.088 & 0.726 \\
\hline Surface chlorophyll, $\mathrm{mg} \mathrm{m}^{-3}$ & 0.699 & $<0.001$ & 0.791 \\
\hline Light attenuation coefficient, $\mathrm{m}^{-1}$ & 0.360 & $<0.001$ & 0.836 \\
\hline
\end{tabular}

A. T. Romarheim et al.

Title Page

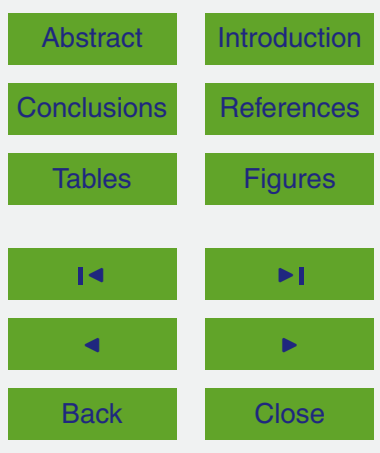

Full Screen / Esc

Printer-friendly Version

Interactive Discussion 


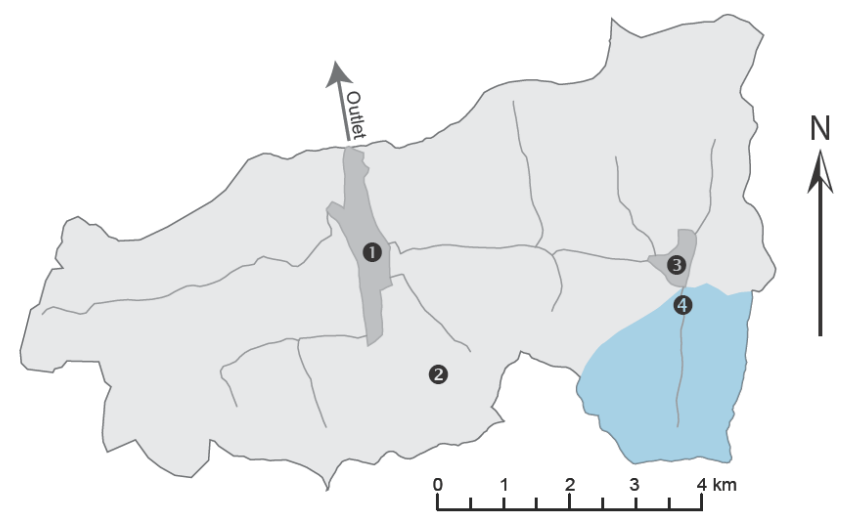

\section{HESSD}

11, 12489-12518, 2014

Natural stochasticity

vs. management

effort

\section{A. T. Romarheim et al.}

\section{Title Page}

Abstract

Introduction

Conclusions

References

Tables

Figures

14

Figure 1. Map of catchment draining into (1) Lake Årungen, with the (2) weather station at Ås, (3) Lake Østensjøvannet and (4) the Skuterud monitoring station. Runoff data from the Skuterud sub-catchment (indicated by dark shading) are scaled up according to land area and usage of the rest of the catchment to estimate the total loading to Lake Årungen.

$<$

Back

Full Screen / Esc

Printer-friendly Version

Interactive Discussion 

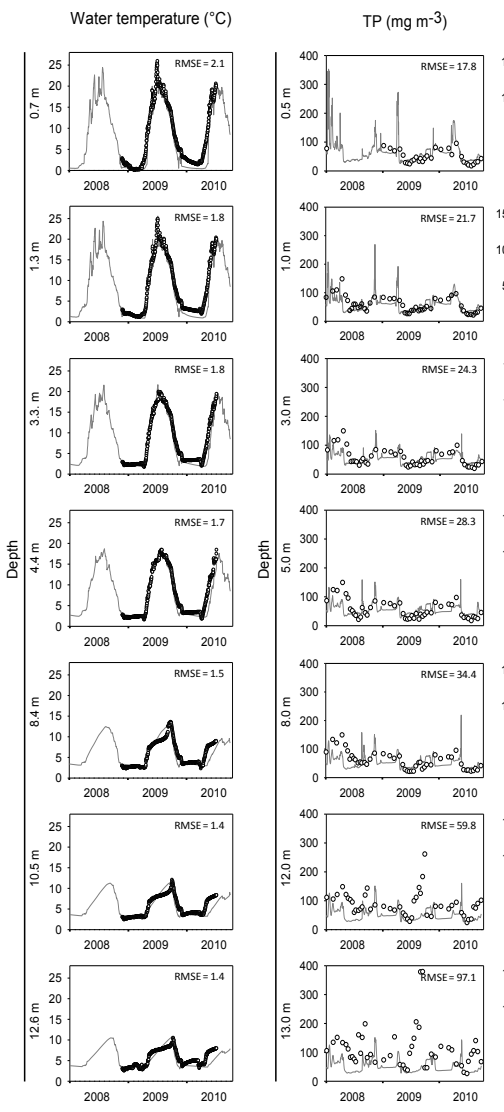

$\operatorname{SRP}\left(\mathrm{mg} \mathrm{m}^{-3}\right)$

Chlorophyll a $\left(\mathrm{mg} \mathrm{m}^{-3}\right)$
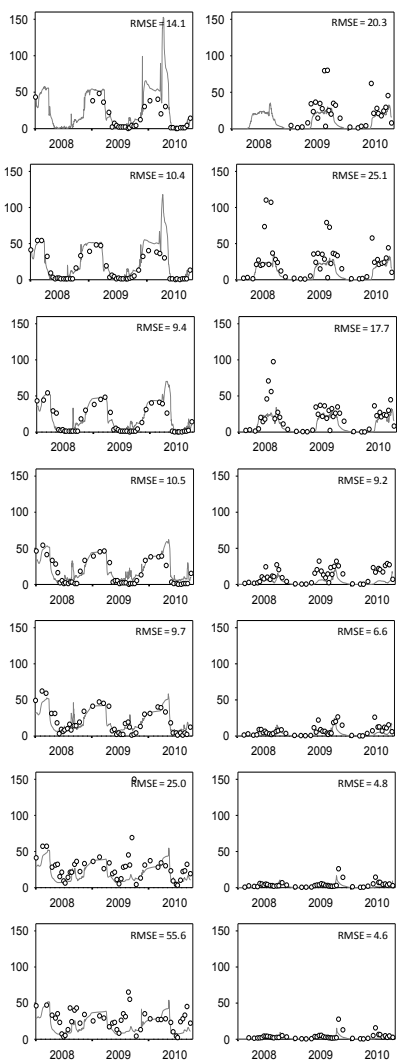

Figure 2. Simulated (line) and observed (circles) lake state variables for water temperature, TP, SRP, and chlorophyll a concentrations at seven depths. RMSE values are in their respective original units, and they are shown only for the presentation purpose and were not used during the calibration. See text for the details of calibration procedure.

\section{HESSD}

$11,12489-12518,2014$

Natural stochasticity

vs. management effort

\section{A. T. Romarheim et al.}

\section{Title Page}

Abstract

Introduction

Conclusions

References

Tables

Figures

14

$\triangleleft$

Back

Close

Full Screen / Esc

Printer-friendly Version

Interactive Discussion 

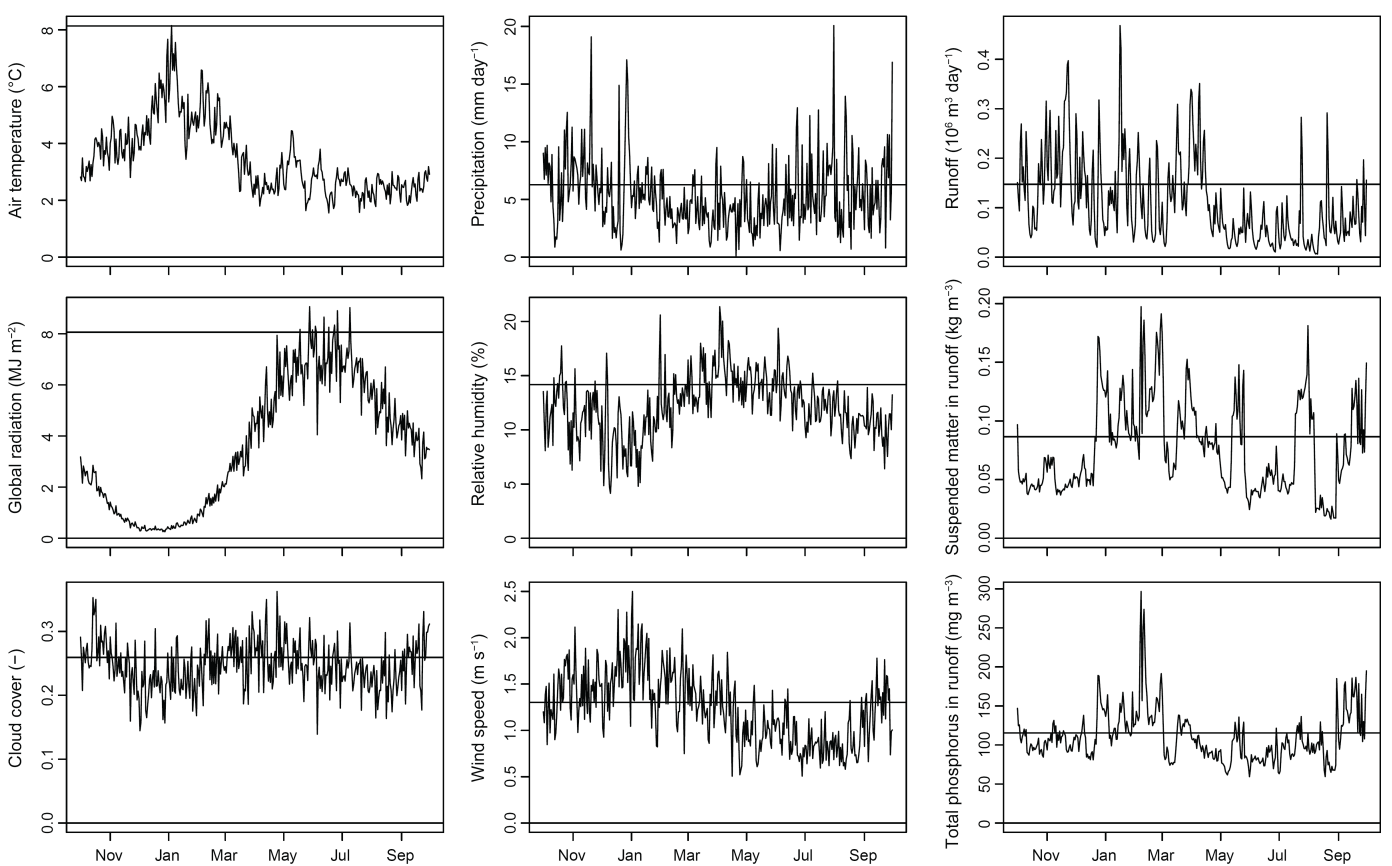

Figure 3. Input variability shown as standard deviations on a water year scale (day-by-day, year-to-year variation, $n=16$, curves), with the overall 16 year standard deviations indicated by horizontal lines.
HESSD

$11,12489-12518,2014$

Natural stochasticity vs. management effort

\section{A. T. Romarheim et al.}

\section{Title Page}

Abstract

Introduction

Conclusions

References

Tables

Figures

14

$\triangleleft$

Back

Close

Full Screen / Esc

Printer-friendly Version

Interactive Discussion

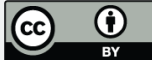



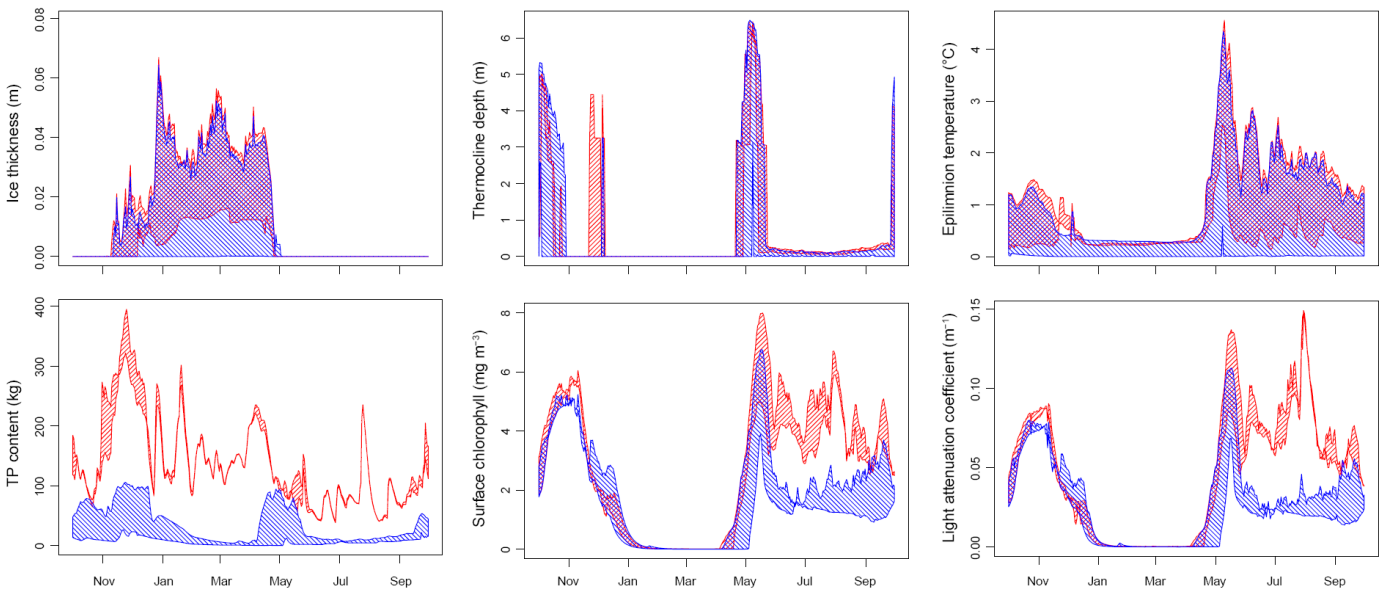

Figure 4. Output variability shown as standard deviations on a water year scale (day-by-day, year-to-year variation, $n=16$ ) for scenarios $\mathrm{A}$ (top of the forward diagonal band), B (bottom of the forward diagonal band), $C$ (top of the backward diagonal band), and $D$ (bottom of the backward diagonal band). Consequently, each panel illustrates $4 \times 365$ standard deviation values, and each standard deviation is based on sample size $n=16$. See Table 3 for scenario configurations.

\section{HESSD}

$11,12489-12518,2014$

Natural stochasticity

vs. management

effort

\section{A. T. Romarheim et al.}

\section{Title Page}

Abstract

Introduction

Conclusions

References

Tables

Figures

14

$<$

Back

Close

Full Screen / Esc

Printer-friendly Version

Interactive Discussion 

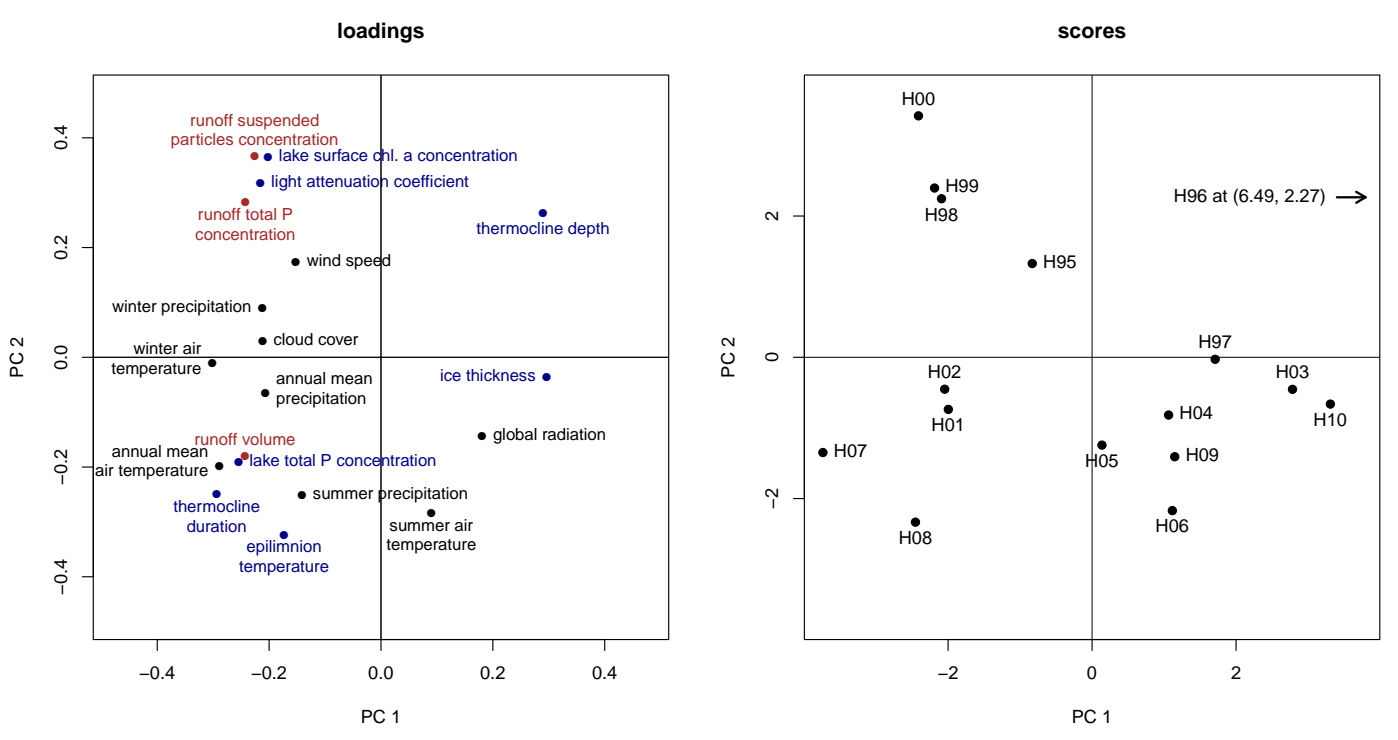

Figure 5. Principal component analysis (PCA) loadings for the two greatest components and scores for the two components for 16 water years (letters).

\section{HESSD}

$11,12489-12518,2014$

Natural stochasticity

vs. management

effort

A. T. Romarheim et al.

Title Page

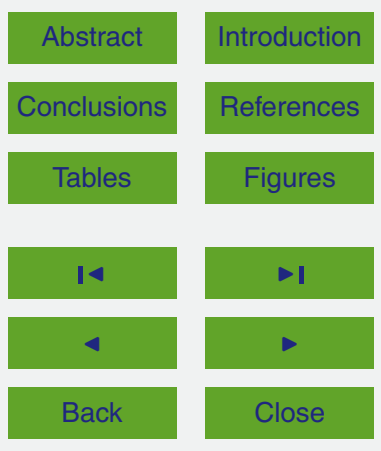

Full Screen / Esc

Printer-friendly Version

Interactive Discussion 